\title{
VIDEOFLUOROSCOPIC EVALUATION OF SWALLOWS IN ANOREXIA NERVOSA
}

\author{
Carla Manfredi SANTOS ${ }^{1}$, Rachel Aguiar CASSIANI ${ }^{1}$ and Roberto Oliveira DANTAS ${ }^{2}$
}

Received 30/3/2016 Accepted 13/5/2016

\begin{abstract}
Background - There are some studies in the literature about the feeding behavior and masticatory process in patients with feeding disorders; however, it is not very well known if there are alterations in oral-pharyngeal swallowing dynamics in subjects with anorexia nervosa. Objective - To evaluate the oral and pharyngeal bolus transit in patients with anorexia nervosa. Methods - The study was conducted with 8 individuals clinically diagnosed and in treatment for restricting-type anorexia nervosa (seven women and one man), and 14 healthy individuals with no digestive or neurological symptoms (10 women, 4 men). Swallows were evaluated by videofluoroscopy with three swallows of $5 \mathrm{~mL}$ liquid bolus and three swallows of $5 \mathrm{~mL}$ paste bolus consistency, given in a random sequence. The participants were asked after each swallow about the sensation of the bolus passage. Results - In the analysis of oral-pharyngeal transit duration, the mean duration of pharyngeal transit with paste bolus in patients with anorexia was shorter than in healthy volunteers $(P=0.02)$. In the duration of movement of the hyoid bone, longer movement was observed in anorexia than in healthy volunteers with liquid bolus $(P=0.01)$. With liquid bolus, five $(62.5 \%)$ patients and one $(7.1 \%)$ control had sensation of the bolus passage $(P<0.05)$. Conclusion - There seems to be no important alterations of swallowing in subjects with anorexia nervosa, although the results suggest that pharyngeal transit has shorter duration than that seen in healthy volunteers and the hyoid movement duration is longer in patients than in healthy volunteers. Fast pharyngeal transit may be the cause of bolus transit perception in patients with anorexia nervosa.
\end{abstract}

HEADINGS - Anorexia nervosa. Deglutition. Deglutition disorders.

\section{INTRODUCTION}

Anorexia nervosa (AN) is a decline in voluntary food ingestion leading to significant loss of body weight, with consequent high risk of morbidity and mortality ${ }^{(21)}$. There is a fear of weight gain and obsession with fatness ${ }^{(16)}$. The disease affects psychosocial functioning and more frequently young women. Depressive factor and low self-esteem are associated with the initiation of the disease ${ }^{(11)}$.

Nutrient deprivation ${ }^{(23,26)}$ and iron deficiency ${ }^{(6,20)}$ may affect muscle and nerve function with the possibility to cause dysphagia. Severe AN is associated with dysphagia ${ }^{(12-14)}$ which could be consequent of psychological factors and/or neuromuscular alterations. Emotional distress may cause dysphagia ${ }^{(1,3)}$, with the possibility of alteration of sensitivity and on the control of swallowing ${ }^{(19)}$. Esophageal motility alterations are described in the disease ${ }^{(2,25)}$ most of the time misleading the diagnosis; oral-pharyngeal dysphagia was found in $42(20.4 \%)$ out of 206 patients with severe $\mathrm{AN}^{(14)}$, without description of alterations of the oral and pharyngeal transit in the disease.
Our objective in this investigation was to evaluate the oral and pharyngeal phases of swallowing in patients with AN. The hypothesis was that patients with AN had swallowing alterations related to emotional distress or neuromuscular alterations caused by the disease.

\section{METHODS}

The study was conducted with eight patients with the diagnosis of restrictive AN. These patients were in treatment in the nutrition and psychiatric divisions of the University Hospital of Ribeirão Preto, seven women and one man, aged 15-49 years (mean 25.9 years), with body mass index (BMI) from $14.8 \mathrm{~kg} / \mathrm{m}^{2}$ to $24.8 \mathrm{~kg} / \mathrm{m}^{2}$ (mean $19.2 \mathrm{~kg} / \mathrm{m}^{2}$ ), four of them with the complain of dysphagia for liquid and solid foods. At the beginning of the treatment all patients meet the criteria for diagnosis of typical $\mathrm{AN}^{(23,24)}$ They did not have, at the time of swallowing evaluation, malnutrition or anemia.

Fourteen healthy volunteers, ten women and four men, aged $15-50$ years (mean 29.6 years), without digestive or neurologic diseases or symptoms, with BMI from $18.3 \mathrm{~kg} / \mathrm{m}^{2}$ to $24.6 \mathrm{~kg} / \mathrm{m}^{2}$ (mean $22.0 \mathrm{~kg} / \mathrm{m}^{2}$ )

Declared conflict of interest of all authors: none

Disclosure of funding: no funding received

${ }^{1}$ Fonoaudiologia, Centro de Reabilitação, Hospital do Estado, Ribeirão Preto, SP, Brasil; ${ }^{2}$ Faculdade de Medicina de Ribeirão Preto, Universidade de São Paulo, Ribeirão Preto, SP, Brasil.

Correspondence: Roberto Oliveira Dantas. Departamento de Medicina, Faculdade de Medicina de Ribeirão Preto, Universidade de São Paulo. CEP: $14049-900$ - Ribeirão Preto, SP, Brasil. Email: rodantas@fmrp.usp.br 
were the control group. The study was conducted at the University Hospital of the Medical School of Ribeirão Preto, University of São Paulo, and the protocol of the investigation was approved by the Human Research Committee of the University Hospital of Ribeirão Preto, protocol HCRP $n^{\circ} 4964 / 2009$. Written informed consent was obtained from each participant and the anonymity of each volunteer and patient was preserved.

Videofluoroscopic evaluation of swallowing was done with the radiologic Arcomax angiograph (Phillips, model BV 300, Veenpluis, The Netherlands). The apparatus recorded 30 frames/ second for posterior analysis. The maximum duration of the tests was 60 seconds. The examination was performed in the lateral position with patients and volunteers seated on a chair.

Three swallows of a $5 \mathrm{~mL}$ liquid bolus and three swallows of a $5 \mathrm{~mL}$ paste bolus were evaluated in a random sequence. The liquid bolus was liquid barium sulfate (Bariogel ${ }^{\circledR} 100 \%$, Laboratório Cristália, Itapira SP, Brazil), and the paste bolus was prepared with $15 \mathrm{~mL}$ of liquid barium and $3 \mathrm{~g}$ of the food thickner Nutilis (Support, São Paulo SP, Brazil), both given to the individual by spoon.

The following were timed features: (1) time the complete bolus volume was inside the mouth; (2) onset of propulsive tongue tip movement at the maxillary incisors; (3) passage of the bolus head through the fauces; (4) passage of the bolus tail through the fauces; (5) onset and end of hyoid movement; (6) onset and offset of upper esophageal sphincter (UES) opening. The duration of the movements during swallowing were measured: (a) oral preparation (OP): complete bolus volume inside the mouth to tongue tip at the maxillary incisors; (b) oral transit (OT): tongue tip at incisors to passage of the bolus tail through the fauces; (c) pharyngeal transit (PT): bolus tail at fauces to offset of UES opening; (d) pharyngeal clearance (PC): bolus head at fauces to the offset of UES opening; (e) UES opening (UESO): time interval between the onset and offset of UES opening; (f) duration of hyoid movement (HM): time interval between the beginning and end of hyoid movement; (g) oral-pharyngeal transit (OPT): interval between the tongue tip at incisors to the offset of UES opening.

The qualitative aspects of swallowing were also evaluated, including the presence of post-swallow oral residues, post-swallow pharyngeal residues, multiple swallows, piecemeal swallows, premature spillage into the pharynx, and the frequency of dipper and tipper swallows. Residues were seen when part of the bolus remained inside the mouth and/or the pharynx after the swallow, in the piriform sinuses and/or vallecula; multiple swallows occurred when the individual needed more than one swallow to clear the bolus from mouth and/or pharynx; piecemeal swallows were seen when the individual fractioned the bolus for swallow; premature spillage occurred when part of the bolus enter inside the pharynx, until vallecula or piriform sinuses, before the start of oral transit; tipper and dipper swallows were classified as previously described ${ }^{(7)}$. The participants were asked after each swallow about the sensation of the bolus passage, with the options of bolus passage without perception of transit or the perception of slow transit, partial blockage or complete blockage.
Statistical analysis was performed by a linear model with mixed effects (random and fixed effects), in which the responses of the same subject are grouped and the assumption of independence between observations within the same group is not appropriate ${ }^{(22)}$. Considered as fixed effects was bolus consistency (liquid and paste), while subjects (patients and controls) were considered to be random effects. For qualitative analysis, Fisher's exact test was used with SAS (version 9) software. In the tables, the results are shown as mean and 95\% Confidence Interval (CI), in milliseconds (ms), and in the figures, the individual results are the mean of the three swallows performed by each patient and control with liquid and paste boluses. The differences were considered significant when $P \leq 0.05$.

\section{RESULTS}

There was no difference between patients and controls in the frequency of oral and pharyngeal residues, multiple swallows, premature spillage into the pharynx, and the frequency of dipper or tipper swallows (Table $1, P>0.05$ ). No patient or healthy volunteer had air way aspiration. For liquid bolus, the frequency of piecemeal swallow was similar between patients $(12.5 \%)$ and controls $(7.1 \%, P=0.99)$, but with paste bolus, the frequency of piecemeal swallow was higher in patients $(62.5 \%)$ than in controls $(14.3 \%, P=0.04)$.

TABLE 1. Oral and pharyngeal evaluation of swallow of liquid and paste boluses in patients with anorexia nervosa $(A N, n=8)$ and controls $(n=14)$. The results are shown in percentage of participants

\begin{tabular}{lcccccc}
\hline & \multicolumn{3}{c}{ Liquid } & \multicolumn{3}{c}{ Paste } \\
& Controls & AN & $\boldsymbol{P}$ & Controls & AN & $\boldsymbol{P}$ \\
\hline $\begin{array}{l}\text { Oral residues } \\
\begin{array}{l}\text { Pharyngeal } \\
\text { residues }\end{array}\end{array}$ & 35.7 & 25.0 & 0.50 & 35.7 & 50.0 & 0.44 \\
$\begin{array}{l}\text { Multiple } \\
\text { swallows }\end{array}$ & 78.6 & 62.5 & 0.70 & 78.6 & 62.5 & 0.70 \\
$\begin{array}{l}\text { Piecemeal } \\
\text { swallows }\end{array}$ & 71.4 & 87.5 & 0.78 & 71.4 & 100.0 & 0.30 \\
$\begin{array}{l}\text { Premature } \\
\text { spillage }\end{array}$ & 42.9 & 12.5 & 0.99 & 14.3 & 62.5 & 0.04 \\
$\begin{array}{l}\text { Tipper swallows } \\
\text { Tipand }\end{array}$ & 71.4 & 87.5 & 0.39 & 57.1 & 87.5 & 0.34 \\
\hline
\end{tabular}

The results of the means and $95 \% \mathrm{CI}$ of the duration of swallowing events are shown in Table 2 for liquid and Table 3 for paste. There was no mean differences for OP, OT, PC, UESO, OPT $(P>0.05)$. The pharyngeal transit duration was longer for controls than for patients with AN (liquid: $487 \mathrm{~ms}$ controls, $426 \mathrm{~ms}$ anorexia; paste: $499 \mathrm{~ms}$ controls, $404 \mathrm{~ms}$ anorexia), but the results were significant only for paste $(P=0.02)$. The duration of hyoid movement was longer for patients than for controls with the liquid bolus (liquid: $864 \mathrm{~ms}$ controls, $1265 \mathrm{~ms}$ anorexia, $P=0.01$; paste: $924 \mathrm{~ms}$ controls, 1166 ms anorexia, $P=0.09$ ). 
TABLE 2. Mean and 95\% confidence interval (CI), in miliseconds, of duration of oral and pharyngeal events in healthy subjects $(n=14)$ and patients with anorexia $(n=8)$, after swallows of liquid bolus

\begin{tabular}{lccccc}
\hline & & Controls & \multicolumn{3}{c}{ Anorexia } \\
& Mean & $95 \%$ CI & Mean & $95 \%$ CI & $P$ \\
\hline OP & 1004 & $823-1185$ & 1802 & $1281-2323$ & 0.08 \\
OT & 363 & $294-432$ & 290 & $267-312$ & 0.71 \\
PT & 487 & $457-517$ & 426 & $384-468$ & 0.18 \\
PC & 858 & $766-949$ & 865 & $540-1191$ & 0.40 \\
UESO & 515 & $483-547$ & 517 & $472-562$ & 0.96 \\
HM & 864 & $778-949$ & 1265 & $963-1566$ & 0.01 \\
OPT & 850 & $773-927$ & 720 & $679-762$ & 0.30 \\
\hline
\end{tabular}

OP: oral preparation; OT: oral transit; PT: pharyngeal transit; PC: pharyngeal clearance; UESO upper esophageal sphincter opening; HM: hyoid movement; OPT: oral-pharyngeal transit.

TABLE 3. Mean and 95\% confidence interval (CI), in miliseconds, of duration of oral and pharyngeal events in healthy subjects $(n=14)$ and patients with anorexia $(n=8)$, after swallows of paste bolus

\begin{tabular}{lccccc}
\hline & & Controls & \multicolumn{3}{c}{ Anorexia } \\
& Mean & $95 \%$ CI & Mean & $95 \%$ CI & $P$ \\
\hline OP & 1948 & $1622-2274$ & 2777 & $1926-3629$ & 0.53 \\
OT & 513 & $329-697$ & 310 & $255-365$ & 0.36 \\
PT & 499 & $469-529$ & 404 & $361-447$ & 0.02 \\
PC & 1095 & $887-1303$ & 903 & $604-1202$ & 0.12 \\
UESO & 545 & $508-581$ & 504 & $467-542$ & 0.47 \\
HM & 924 & $853-995$ & 1166 & $963-1368$ & 0.09 \\
OPT & 1017 & $819-1216$ & 735 & $668-801$ & 0.09 \\
\hline
\end{tabular}

OP: oral preparation; OT: oral transit; PT: pharyngeal transit; PC: pharyngeal clearance; UESO upper esophageal sphincter opening; HM: hyoid movement; OPT: oral-pharyngeal transit.

With liquid bolus, five $(62.5 \%)$ patients and one $(7.1 \%)$ control had the sensation of slow transit or partial blockage $(p<0.05)$ and with paste bolus, the sensation was seen in seven $(87.5 \%)$ patients and nine $(64.3 \%)$ controls $(P>0.05)$.

Figure 1 shows the results for pharyngeal transit duration, Figure 2 for oral-pharyngeal transit duration and Figure 3 for hyoid movement duration. They demonstrated the trend towards shorter transit duration and a longer duration of hyoid movement in patients with anorexia nervosa.

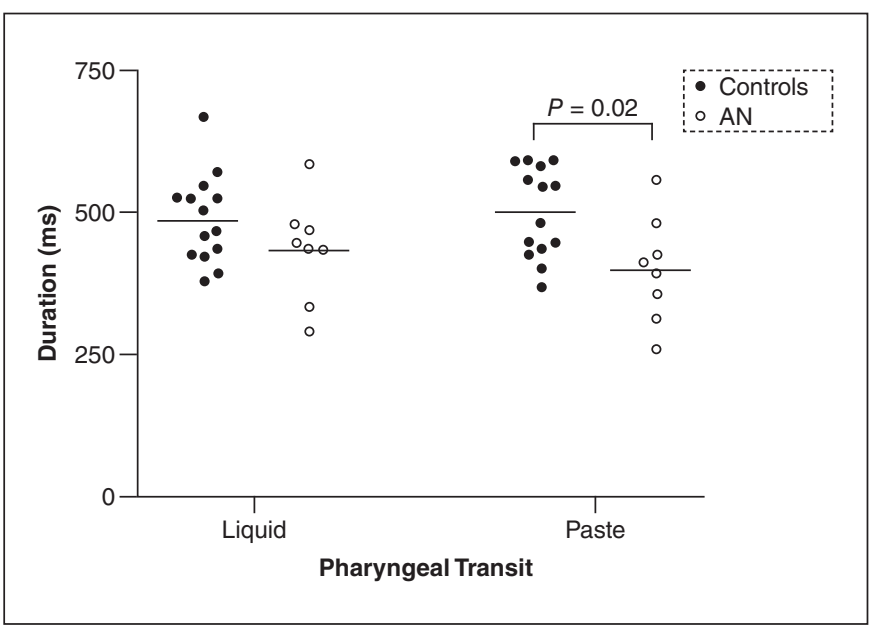

FIGURE 1. Pharyngeal transit duration, in milleseconds ( $\mathrm{ms}$ ), in patients with anorexia nervosa (AN) and controls after swallows of $5 \mathrm{~mL}$ of liquid and paste bolus.

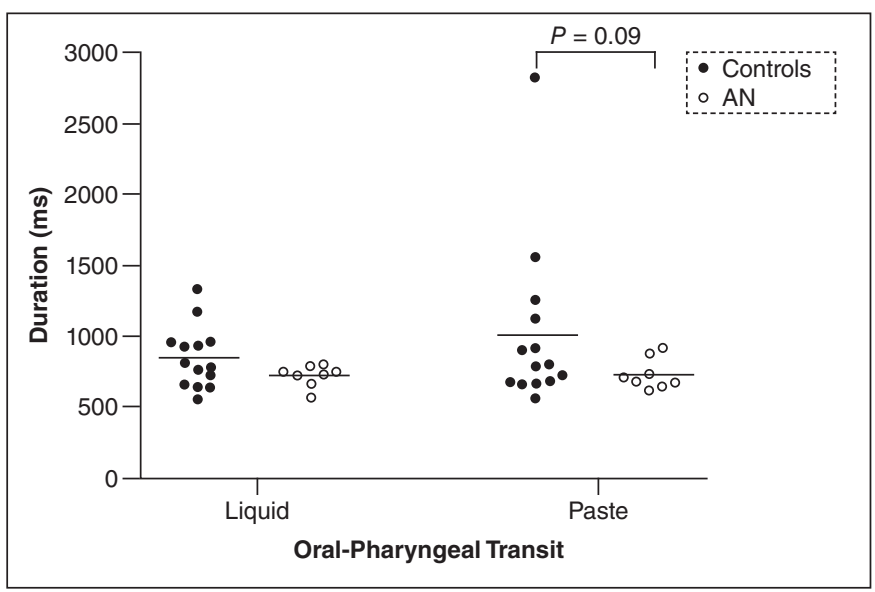

FIGURE 2. Oral-pharyngeal transit duration, in milleseconds (ms), in patients with anorexia nervosa (AN) and controls after swallows of $5 \mathrm{~mL}$ of liquid and paste bolus.



FIGURE 3. Hyoid movement duration, in milleseconds (ms), in patients with anorexia nervosa $(\mathrm{AN})$ and controls after swallows of $5 \mathrm{~mL}$ of liquid and paste bolus. 


\section{DISCUSSION}

Although significant differences were seen only in a few comparisons, the results suggested that patients with AN have a short duration of pharyngeal bolus transit and a longer hyoid movement during bolus transit. The observed alterations and reduced food intake may be consequent of inhibitory factors as cognitive inhibition related to fear of weight gain, abnormal post-ingestive negative feedback and a possible reduction in orosensory stimulation by food intake ${ }^{(18)}$. The initiation of the restrictive eating is associated with low self-stem and depression ${ }^{(11)}$. It is possible that the four patients with dysphagia of this investigation had psycogenic dysphagia, but alteration of swallowing physiology is also a possibility ${ }^{(13,14)}$. Bolus aspiration inside the air was not found in any patient and control.

As swallowing evaluation was performed in patients who did not have severe malnutrition and/or iron deficiency anemia, which could justify alterations in pharyngeal physiology, alterations in esophageal contractions and the occurrence of dysphagia ${ }^{(6,20,26)}$, intense swallowing impairment was not expected. However psychologic factors were present, which could alter swallowing function ${ }^{(8,11,15,17)}$. The sensation of bolus transit during swallowing was more frequent in patients than in controls for liquid bolus which raises the possibility that for them the swallow causes some concern or a different oral, pharyngeal and/or esophageal transit. This perception could justify the dysphagia referred by some patients.

Esophageal manometry performed on severe AN patients has found achalasia, diffuse esophageal spasm, upper esophageal sphincter hypertonicity, non-propulsive repetitive high amplitude contraction, but these results have come from patients with suspected esophageal diseases ${ }^{(25)}$. In another study, patients with AN were described to have increased lower esophageal sphincter pressure and an increase in contraction amplitude ${ }^{(2)}$. The esophageal hypercontractility may be consequent of liberation of stress hormone, as corticotrophin releasing hormone ${ }^{(10)}$, which could contribute to dysphagia referred by the patients. The faster transit found in the pharyngeal phase of swallowing with the paste bolus could be an adaptation to a possible esophageal motility alteration.

Oral-pharyngeal swallowing is a complex function which needs perfect coordination in respiration/deglutition. For a safe swallow, the pharyngeal reconfiguration from respiratory organ to digestive organ should be very precise.
The swallowing has the control of the brain stem, has cortical influence and depends on the sensitivity of mouth, pharynx and esophagus ${ }^{(19)}$. It is possible that patients with severe AN have decreased oral sensitivity, an imperfect coordination respiration/deglutition, causing air way aspiration ${ }^{(13)}$, but the decrease in food ingestion probably is a learned behavior ${ }^{(18)}$. Recent results showed that among patients with severe AN and oral-pharyngeal dysphagia $56 \%$ had laryngeal penetration and $16 \%$ had aspiration ${ }^{(14)}$, results not observed in our patients, who were not in a severe phase of the disease.

AN has influence on brain structure, with description of smaller brain volume, decrease in grey matter volume ${ }^{(9)}$, reduction in hippocampal fimbria, enlargement of the hippocampal fissure, with the possibility that the perceived stress in patients with $\mathrm{AN}$ be related with hippocampal volume $^{(4)}$. These patients have an increase in stress ${ }^{(9)}$, which can affect brain-gut interaction and the function of the digestive tract ${ }^{(5,10)}$. The observed anatomic alterations may have influence in the control of swallowing.

Our study has some limitations. The number of patients with AN included in the study was small, consequent of the number of patients in treatment in the hospital, the refusal to participate by patients who did not want to have their swallows evaluated, and the situation of depression they had at the moment of investigation. The patients were in treatment and were experiencing improvement of disease status compared with the moment of diagnosis and the start of treatment. The patients were not at the same stage of the disease. These are situations that need to be dealt with during an investigation of this disease. However, the possible alterations observed are sufficient evidence to support further investigations. The observed alterations should be a consequence of $\mathrm{AN}$ not the cause of eating restriction.

In conclusion, the results suggested that in AN, pharyngeal transit has shorter duration than that seen in healthy volunteers. The differences, shorter pharyngeal transit and longer hyoid movement duration, should be influenced by the psychological features of anorexia nervosa. Further investigation is needed for a complete characterization of swallowing in these patients.

\section{Authors' contributions}

Santos CM, Cassiani RA and Dantas RO, had participation in the planning, investigation, in the preparation of the manuscript, and approved the submission to Arquivos de Gastroenterolgia. 
Santos CM, Cassiani RA, Dantas RO. Avaliação videofluoroscopica da deglutição na anorexia nervosa. Arq Gastroenterol. 2016,53(3):136-40.

RESUMO - Contexto - Existem alguns estudos na literatura sobre o comportamento alimentar e da mastigação em pacientes com distúrbios da alimentação, no entanto não é conhecido se há alterações na dinâmica da deglutição em indivíduos com anorexia nervosa. Objetivo - Avaliar o trânsito oral e faríngeo em pacientes com anorexia nervosa. Métodos - O estudo foi realizado em 8 indivíduos com diagnóstico e em tratamento para anorexia nervosa do tipo restritivo (sete mulheres e um homem), e 14 indivíduos saudáveis, sem sintomas digestivos ou neurológicos (10 mulheres e 4 homens). Os trânsitos oral e faríngeo foram avaliados por videofluoroscopia, com três deglutições de $5 \mathrm{~mL}$ de bolo líquido e três deglutições de $5 \mathrm{~mL}$ de bolo na consistência pastosa, ingeridos em sequência aleatória. Os participantes foram arguidos, após cada deglutição, sobre a sensação da passagem do bolo. Resultados - A duração do trânsito faríngeo com o bolo pastoso, em pacientes com anorexia, foi mais curta do que em voluntários saudáveis $(P=0,02)$. Com bolo líquido a duração do movimento do osso hióide foi mais longa na anorexia do que em voluntários saudáveis $(P=0,01)$. Com bolo líquido, cinco $(62,5 \%)$ pacientes e um controle $(7,1 \%)$ tiveram sensação da passagem de bolus $(P<0,05)$. Conclusão - Não parece haver importantes alterações da deglutição em pacientes com anorexia nervosa, embora os resultados indiquem que o trânsito faríngeo tem duração mais curta do que a observada em voluntários saudáveis e a duração do movimento do hióide é maior em pacientes do que em voluntários saudáveis. O trânsito faríngeo rápido pode ser a causa da percepção da passagem do bolo em pacientes com anorexia nervosa.

DESCRITORES - Anorexia nervosa. Deglutição. Transtornos de deglutição.

\section{REFERENCES}

1. Barofsky I, Fonfaine KR. Do psychogenic dysphagia patients have an eating disorder? Dysphagia. 1998;13:24-7.

2. Benini L, Todesco T, Frulloni L, Dalle Grave R, Campagnola P, Agugiaro F, et al. Esophageal motility and symptoms in restricting and binge-eating/purging anorexia. Dig Liver Dis. 2010;42:767-72.

3. Bretan O, Henry MA, Kerr-Correa F. Dysphagia and emotional distress. Arq Gastroenterol. 1996;33:60-5

4. Burkert NT, Koschutnig K, Ebner F, Freidl W. Structural hippocampal alterations, perceived stress, and coping deficiencies in patients with anorexia nervosa. Int J Eat Disord. 2015;48:670-6.

5. Cook IJ, Dent J, Shannon S, Collins SM. Measurement of upper esophageal sphincter pressure. Effect of acute emotional stress. Gastroenterology. 1987;93:526-32.

6. Dantas RO, Villanova MG. Esophageal motility impairment in Plummer-Vinson syndrome. Correction by iron treatment. Dig Dis Sci. 1993;38:968-71.

7. Dodds WJ, Taylor AJ, Stewart ET, Kern MK, Logemann JA, Cook IJ. Tipper and dipper types of oral swallows. AJR Am J Roentgenol. 1989;153:1197-9.

8. Eslick GD, Talley NJ. Dysphagia: epidemiology, risk factors and impact on quality of life - a population-based study. Aliment Pharmacol Ther. 2008;27:971-9.

9. Fonville L, Giampietro V, Williams SC, Simmons A, Tchanturia K. Alterations in brain structure in adults with anorexia nervosa and the impact of illness duration. Psychol Med. 2014;44:1965-75.

10. Fukudo S, Nomura T, Hongo M. Impact of corticotropin-releasing hormone on gastrointestinal motility and adrenocorticotropic hormone in normal controls and patients with irritable bowel syndrome. Gut. 1998;42:845-9.

11. Haynos AF, Watts AW, Loth KA, Pearson CM, Neumark-Stzainer D. Factors predicting an escalation of restrictive eating during adolescence. J Adolesc Health 2016; in press. doi: 10.1016/j.jadohealth.2016.03.011

12. Holmes SR, Gudridge TA, Gaudiani JL, Mehler PS. Dysphagia in severe anorexia nervosa: a case report. Int J Eat Disord. 2012;45:463-6.

13. Holmes SR, Gudridge TA, Gaudiani JL, Mehler PS. Dysphagia in severe anorexia nervosa and potential therapeutic intervention: a case series. Ann Otol Rhinol Laryngol. 2012;121:449-56.
14. Holmes SR, Sabel AL, Gaudiani JL, Gudridge T, Brinton JT, Mehler PS. Prevalence and management of oropharyngeal dusphagia in patients with severe anorexia nervosa: a large retrospective review. Int J Eat Disord. 2016; 49:159-66.

15. Kang SS, Lee JS, Shin JK, Lee JM, Youn BH. The association between psychiatric factors and the development of chronic dysphagia after anterior cervical spine surgery. Eur Spine J. 2014;23:1694-8.

16. Kaye W. Neurobiology of Anorexia and Bulimia Nervosa Purdue Ingestive Behavior Research Center Symposium Influences on Eating and Body Weight over the Lifespan: Children and Adolescents. Physiol Behav. 2008;94:121-35.

17. Kelly AC, Tasca GA. Within-persons predictors of change during eating disorders tretment: an examination of self-compassion, self criticism, shame, and eating disorder symptoms. Int J Eat Disord 2016; in press. doi: 10.1002/eat.22527.

18. Klein DA, Schebendach JE, Gershkovich M, Smith GP, Walsh BT. Modified sham feeding of sweet solutions in women with anorexia nervosa. Physiol Behav. 2010;101:132-40.

19. Lang IM. Brain stem control of the phases of swallowing. Dysphagia. 2009;24:333-48.

20. Miranda AL, Dantas RO. Esophageal contractions and oropharyngeal and esophageal transits in patients with iron deficiency anemia. Am J Gastroenterol. 2003;98:1000-4.

21. Podfigurna-Stopa A, Czyzyk A, Katulski K, Smolarczyk R, Grymowicz M, Maciejewska-Jeske M, et al. Eating disorders in older women. Maturitas. 2015;82:146-52.

22. Schall R. Estimation in generalized linear models with random effects. Biometrika. 1991;78:719-27.

23. Sidiropoulos M. Anorexia nervosa; the physiological consequences of starvation and the need for primary prevention efforts. McGill J Med. 2007;10:20-5.

24. Silen Y, Raevuori A, Juriloo E, Tainio VM, Marttunen M, Keski-Rahkonen A Typical Versus Atypical Anorexia Nervosa Among Adolescents: Clinical Characteristics and Implications for ICD-11. Eur Eat Disord Rev. 2015;23:345-51.

25. Stacher G, Kiss A, Wiesnagrotzki S, Bergmann H, Hobart J, Schneider C. Oesophageal and gastric motility disorders in patients categorised as having primary anorexia nervosa. Gut. 1986;27:1120-6.

26. Veldee MS, Peth LD. Can protein-calorie malnutrition cause dysphagia? Dysphagia. 1992;7:86-101 